\title{
Trace Elements in Man and Animals 6
}




\section{Trace Elements in Man and Animals 6}

Edited by

Lucille S. Hurley,

Carl L. Keen,

Bo Lönnerdal, and Robert B. Rucker

University of California, Davis

Davis, California

PLENUM PRESS • NEW YORK AND LONDON 


\section{Library of Congress Cataloging in Publication Data}

International Symposium on Trace Elements in Man and Animals (6th: 1987: Pacific Grove, Calif.)

Trace elements in man and animals 6 / edited by Lucille S. Hurley, . . [ [et al.].

p. $\quad \mathrm{cm}$.

"Proceedings of the Sixth International Symposium on Trace Elements in Man and Animals, held May 31-June 5, 1987, in Pacific Grove, California"-T.p. verso.

Includes bibliographical references and index.

ISBN-13:978-1.4612-8050-7

e-ISBN-13:978-1.4613-0723.5

DOI: $10.1007 / 978 \cdot 1 \cdot 4613 \cdot 0723.5$

1. Trace elements in the body-Congresses. 2. Trace elements-Physiological effect-Congresses. 3. Trace elements in nutrition-Congresses. I. Hurley, Lucille S. II. Title.

Proceedings of the Sixth International Symposium on

Trace Elements in Man and Animals, held May 31-June 5, 1987, in Pacific Grove, California

(c) 1988 Plenum Press, New York

Softcover reprint of the hardcover 1st edition 1988

A Division of Plenum Publishing Corporation

233 Spring Street, New York, N.Y. 10013

All rights reserved

No part of this book may be reproduced, stored in a retrieval system, or transmitted in any form or by any means, electronic, mechanical, photocopying, microfilming, recording, or otherwise, without written permission from the Publisher 
PREFACE

This book is the published proceedings of the Sixth International Symposium on Trace Element Metabolism in Man and Animals. The Symposium was held at the Asilomar Conference Center in Pacific Grove, California, U.S.A. from May 31 through June 5, 1987. The decision to hold TEMA-6 at Asilomar was made at TEMA-5 in 1985. The International Guidance Committee decided to hold the meeting in California in part to recognize the significant contributions made to the field of trace element metabolism by Professor Lucille S. Hurley. As such, she was the obvious choice as chair of the local organizing committee. One of the principal goals of Professor Hurley was that TEMA-6 serve as a forum for discussing the use and application of newer methodologies, such as molecular biology, computer modelling and stable isotopes, in studies of trace element metabolism. Based on the comments which the local organizing committee has received, this goal was achieved.

The Symposium was attended by 275 scientists from 32 countries covering 6 continents. Twenty-five speakers were chosen for our plenary sessions. One hundred contributions were presented verbally and an additional 180 were presented as posters. Particularly gratifying to the Organizing Committee was the high attendance at both the evening sessions as we 11 as those on the last day of the meeting, suggesting that, despite the pleasant surroundings of the Carmel Valley, the topics presented were of interest to all participants. We would like to express our sincere thanks to all the participants and session chairs for their valuable contributions. We are also very grateful to the members of the International Guidance Committee for their assistance in arranging this meeting, and to the graduate students in attendance from the University of California, Davis, who assisted in various ways in keeping the meeting running smoothly. Moreover, the editors also thank Ms. Barbara Brandon and Ms. Carol Biancalana for their excellent secretarial and managerial assistance, without which this book would not have been published in the timely fashion that it has been.

In August of 1988 we received the first galleys for this book, which were proofed by Professor Hurley, who expressed at the time her satisfaction with the Proceedings. It was a tremendous shock to us when, a few weeks later, Professor Hurley died from complications arising from surgery. The members of the local organizing committee would like to hope that, in some small way, the Proceedings of this meeting serve as a memorial to Professor Hurley and the outstanding scientific as well as personal contributions that she made to the field of trace element metabolism.

C. L. Keen, B. Lbnnerda1 and R. B. Rucker, Davis, 1988. 
CONTENTS

SELENIUM

The Global Selenium Agenda . . . . . . . . . . . . . . . . 1

0 . A. Levander

The Predicament -- How Should Selenoproteins be Hydrolyzed and Bioavailability Studies with Selenium Conducted? . . . . . . 7

P. D. Whanger

Bioavailability of Selenium in Wheat and Mushrooms as Assessed

by a Short-term and a Long-term Experiment . . . . . . . . . . . 9

M. Vainio, M. Mutanen, and H. Mykkunen

Selenium Status During Recovery from Malnutrition: Effect of Selenium Supplementation . . . . . . . . . . . . . 11

C. Murphy, B. Golden, D. Ramdath, and M. Golden

Selenium and Glutathione Peroxidase in Mothers Experiencing Sudden Infant Death Syndrome . . . . . . . . . . . . . . .

J. Valentine, B. Faraji, and K. Akashi

Selenium Responsive Conditions and the Concentrations of Selenium in Skeletal Muscle in Young Sheep . . . . . . . . . . . .

D. W. Peter, D. J. Buscall, and P. Young

Selenium Status Improved Among Elderly Due to Selenium-Enrichment of Fertilizers in Finland . . . . . . . . . . . . . . . . .

M. Tolonen, M. Halme, S. Sarna, T. Westermarck, U.-R. Nordberg, and $\mathrm{W}$. Bayer

Apparent Proteolytic Modification of Glutathione Peroxidase . . . .

R. A. Sunde, S. A. B. Knight, T. W. Geyman, and J. K. Evenson

\section{ELECTRON TRANSPORT AND METALLOPROTEINS}

Long-Range Electron Transfer in Ruthenium-Modified Proteins . . . .

C. M. Lieber, J. L. Karas, S. L. Mayo, A. W. Axup, M. Albin,

R. J. Crutchley, W. R. Ellis, Jr., and H. B. Gray 
Factors Controlling the Rates of Electron Transfer in Proteins . . .

D. Whitford, D. W. Concar, Y. Gao, G. J. Pielak, and R. J. P. Williams

Kinetic Lability of $\mathrm{Zn}$ Bound to Metallothionein (Mt) in Ehrlich Cells

D. Petering, S. Krezoski, J. Villalobos, and C. F. Shaw III

The Cu-Thiolate Cluster in Mutants of Yeast Metallothionein . . . .

D. R. Winge

Accumulation of Hepatic $\mathrm{Zn}$ and $\mathrm{Zn} / \mathrm{Cu}$ Metallothionein in Copper-

Loaded Chicks: Isolation and Characterization . . . . . .

C. C. McCormick and L.-Y. Lin

Factors Influencing the Accumulation of Metallothionein in Rat

Blood Cells . . . . . . . . . . . . . . . .

J. N. Morrison, A. M. Wood, and I. Bremner

TRACE ELEMENTS AND ENDOCRINE/EXOCRINE FUNCTION: Mn, Zn, Se

Regulation of Pancreatic Exocrine Function by Manganese . . . . .

M. Korc and P. M. Brannon

Effect of Manganese Deficiency on Glucose Transport and Insulin

Binding in Rat Adipocytes . . . . . . . . . . . .

D. L. Baly

Zinc Absorption in Pancreatic Insufficiency ............

W. S. Watson, G. McLauchlan, T. D. B. Lyon, I. Pattie, and

G. P. Crean

Identification of Abnormal Sites of $\mathrm{Zn}$ Transport and Metabolism in

Patients with Sensory and Endocrine Disorders . . . . . . .

M. E. Wastney, D. M. Foster, and R. I. Henkin

Selenium and Selenoproteins in Tissues with Endocrine Functions . .

D. Behne, H. Gessner, H. Hilmert, and S. Scheid

The Effect of Selenium Deficiency on Plasma Thyroid Hormone

Concentrations and on Hepatic Tri-Iodothyronine Production . . .

J. R. Arthur, F. Nicol, and G. J. Beckett

\section{CHELATION AND OTHER VEHICLES FOR THERAPY}

Pyridoxal Isonicotinoyl Hydrazone (PIH) and its Analogues: A New

Group of Effective Chelators . . . . . . . . . . . . . .

P. Ponka, H. M. Schulman, and J. Edward

Iron Toxicity and Chelating Therapy . . . . . . . . . . . .

C. Hershko, G. Link, A. Pinson, S. Sarel, S. Grisaru,

Y. Hasin, and R. W. Grady

Toxic and Essential Metal Loss During Chelation Therapy of

Lead-Poisoned Children . . . . . . . . . . . . .

D. J. Thomas and J. J. Chisolm, Jr.

Use of Metal Chelating Agents to Modulate Ehrlich Ce11 Growth

Multiple Metal-Ligand Interactions . . . . . . . . . . .

D. H. Petering, S. Krezoski, D. Lehn, D. Stone, and H. Loomans 
Effects of Chelating Compounds Formed on Food Processing on Zinc

Metabolism in the Rat . . . . . . . . . . . . . . .

D. E. Furniss, J. Vuichoud, P.-A. Finot, and R. F. Hurre11

Changes in Zinc Metabolism During the Use of EDTA . . . . . . . .

H. Spencer, S. K. Agrawa1, S. J. Sontag, and D. Osis

\section{TRACE ELEMENTS AND IMMUNE FUNCTION}

Trace Element Deficiencies and Immune Responsiveness . . . . . . .

M. E. Gershwin, C. L. Keen, M. P. Fletcher, and L. S. Hurley

Immune Responses as Parametres for Selenium Tolerance

Determination in Sheep . . . . . . . . . . . . . . . . . .

K. Moksnes, H. J. Larsen, and G. Øvernes

The Mobilization of Storage Iron as a Determinant of Refeeding

Infection . . . . . . . . . . . . . . . . . .

M. J. Murray and A. B. Murray

Inflammation-Related Changes in Trace Elements, GSH-Metabolism, Prostaglandins, and Sialic Acid in Bovine Mastitis . . . . . .

F. Atroshi, S. Sankari, J. Tyßppönen, and J. Parantainen

The Effects of Dietary Mo on Ovine Host and Intestinal Parasite . .

N. Suttle, D. Knox, and F. Jackson

TRACE ELEMENTS AND ENDOCRINE/EXOCRINE FUNCTION: $\mathrm{Cu}, \mathrm{Ca}, \mathrm{I}$

Influence of Hormones on Copper Metalloprotein Levels . . . . . .

R. A. DiSilvestro

Norepinephrine and Dopamine Distribution in Copper-Deficient Mice .

J. R. Prohaska and K. L. DeLuca

Effect of Copper Deficiency on Enzyme Secretion from Isolated

Pancreatic Acini . . . . . . . . . . . . . . . . .

M. A. Dubick and A. P. N. Majumdar

Differential Effect of Copper Deficiency on Plasma Atrial

Natriuretic Peptides in Male and Female Rats.......... .

S. J. Bhathena, B. W. Kennedy, P. Marsh, M. Fields, and N. Zamir

Sexual Differences in Copper Deficiency . . . . . . . . . . . .

M. Fields, C. G. Lewis, T. Beal, J. C. Smith, and S. Reiser

Calmodulin Concentration in Tissues of Zinc and Calcium Deficient

Rats . . . . . . . . . . . . . . . . . .

H.-P. Roth and M. Kirchgessner

Effect $\$_{4}$ of Calmgdylin Inhibitors on the Cellular Metabolism of

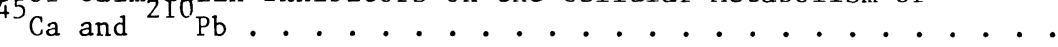

J. G. Pounds and A. C. Nye

Effect of Moderate Environmental Iodine Deficiency on Adolescent Girls . . . . . . . . . . . . . . . .

R. Krishnamachari 
Transport, Subcellular Distribution and Export of Mn(II) in Rat

Liver and Hepatocytes ...............

M. Brandt, C. L. Keen, D. E. Ash, and V. L. Schramm

Extrace1lular Transport of Trace Elements . . . . . . . . . 129

C. J. A. Van den Hamer

Incorporation of Copper into Superoxide Dismutase in Culture . . . .

E. D. Harris and C. T. Dameron

The Role of Albumin in Copper Uptake by Hepatocytes and Fibroblasts .

H. J. McArdle, S. M. Gross, and D. M. Danks

Structure and Function of Transcuprein, in Transport of Copper by

Mammalian Blood Plasma . . . . . . . . . . . . .

M. C. Linder, K. C. Weiss, and V. M. Hai

Differences in Cu-Transport by Hepatocytes and Fibroblasts . . . .

G. L. Waldrop, F. Palida, M. Hadi, P. Lonergan, and M. Ettinger

Neonatal and Adult ${ }^{64}$ Copper Metabolism in the Pig and Its

Relationship to Copper Metabolism in Wilson's Disease . . . .

S. K. S. Srai, C. Bingle, and 0. Epstein

\section{EPIDEMIOLOGICAL STUDIES OF TRACE ELEMENT} NUTRITION IN MAN AND ANIMALS

The Role of Selenium in Special Endemic Diseases and Cancer in China .

J. Chen

Wildlife as Indicators of Enzootic Selenium Deficiency . . . . .

D. E. Ullrey

An Epidemiological Study of a Defined Area of N. Ireland:

Serum $\mathrm{Zn}$ and $\mathrm{Cu}$....................

D. McMaster, A. E. Evans, E. McCrum, M. McF. Kerr,

C. C. Patterson, and A. H. G. Love

Zinc, Iron and Copper in the Nutrition of Australian Aboriginal

Children . . . . . . . . . . . . . . . . . .

R. M. Smith, R. A. King, R. M. Spargo, D. B. Cheek, and J. B. Field

A Re-Appraisal of the Recommended Zinc Requirements for Grazing Livestock

C. L. White

The Utilization of Hens' Eggs as a Selenium Monitor in Epidemiological Studies . . . . . . . . . . . . . .

P. Brbtter, V. E. Negretti de Brbtter, U. Rbsick, and H. Mendez C.

Mineral and Trace Element Nutrition of Sheep in Gansu Province, Northern China ...................

S. X. Yu, D. G. Masters, Q. Su, Z. S. Wang, Y. Q. Duang, and D. B. Purser 
The Epistemology of Trace Element Balance and Interaction . . . . . 173

B. Momcilovic

Subcellular Changes and Metal Mobilisation in the Livers of

Copper-Loaded Rats . . . . . . . . . . . . . . . . . .

I. C. Fuentealba and S. Haywood

The Interactions among $\mathrm{Fe}, \mathrm{Zn}$ and $\mathrm{Cu}$ Affecting Liver $\mathrm{Cu}$ and Femur

Zn Concentrations in the Rat . . . . . . . . . . . . . .

D. T. Gordon and M. Ellersieck

Interactions between Zinc and Vitamin A Metabolism in Rats and Swine.

M. Kirchgessner, F. X. Roth, and H.-P. Roth

Zinc, Copper and Iron Concentrations in Tissues of Anencephalic and Control Fetuses . . . . . . . . . . . . . . . . .

D. Fehily, C. Keohane, F. M. Cremin, and D. M. Jenkins

Effects of Dietary Boron, Aluminum and Magnesium on Serum Alkaline Phosphatase, Calcium and Phosphorus, and Plasma Cholesterol in Postmenopausal Women . . . . . . . . . . . . . . . .

F. H. Nielsen, L. M. Mullen, S. K. Gallagher, J. R. Hunt, C. D. Hunt, and L. K. Johnson

Trace Elements in Infancy: a Supply/Demand Perspective . . . . . . .

B. Lonnerdal

\section{TRACE ELEMENTS AND DEVELOPMENT}

Trace Elements in Malnourished Populations . . . . . . . . . .

M. H. N. Golden and B. E. Golden

The Role of Zinc in Prenatal and Postnatal Development . . . . . . .

C. L. Keen, M. S. Clegg, B. Lonnerda1, and L. S. Hurley

Teratogenesis as a Function of Maternal Age in Zinc-Deficient Rats .

I. R. Record and I. E. Dreosti

Zinc Supplements in Infants with Failure to Thrive:

Effects on Growth . . . . . . . . . . . . . . . . . . . . . .

P. A. Walravens, K. M. Hambidge, and D. M. Koepfer

Zinc Retention in Relationship to Fat-Free Body and Calcium Accretion in Early and Late Pregnancy . . . . . . . . . . . .

J. C. King, C. A. Swanson, D. D. Marino, and F. M. Costa

Zinc (Zn) Absorption in Premature Infants . . . . . . . . . . . . .

P. L. Peirce, K. M. Hambidge, P. V. Fennessey, L. Miller, and C. H. Goss

Zinc Balance in Premature Infants Fed Their Mothers' Milk:

Effect of Postnatal Age . . . . . . . . . . . . . . . .

S. A. Atkinson, D. Fraser, R. Stanhope, and R. Whyte 
Trace Mineral and Calcium Interactions . . . . . . . . . . . . .

K. T. Smith and J. T. Rotruck

Dietary Phytate:Zinc and Phytate $\mathrm{x}$ Calcium:Zinc Ratios of Lacto-0vo Vegetarian Trappist Monks . . . . . . . . . . . . . . . 229

B. F. Harland, S. A. Smith, R. Ellis, M. P. Howard, and R. D. Reynolds

Zinc, Iron and Copper Interactions in Humans, Rats and Chicks . . .

J. L. Greger, M. L. Storey, J. L. Stahl, M. E. Cook, S. E. Gentry-Roberts, and J. C. Lynds

Inhibition of Iron Absorption in Man by Manganese and Zinc . . . . .

L. Hallberg, L. Rossander, M. Brune, B. Sandstrbm, and B. Lonnerda1

Lipid Parameters in Wilson's Disease Patients on Zinc Therapy . . .

G. M. Hill, G. J. Brewer, M. M. McGinnis, and W. D. Block

Effects of Modest Amounts of Wheat Bran and Dietary Protein on Mineral Metabolism of Humans . . . . . . . . . . . . . .

H. H. Sandstead, F. R. Dintzis, J. R. Mahalko, L. K. Johnson, and T. P. Bogyo

\section{TRACE ELEMENTS AND FREE RADICALS}

First Description of a Variant of E. coli Lacking Superoxide Dismutase Activity Yet Able to Grow Efficiently on Minimal, Oxygenated Medium . . . . . . . . . . . . . .

J. A. Fee, E. C. Neiderhoffer, and C. Naranjo

Effect of Selenium (Se) on Peroxidation and Glutathione (GSH) Levels in Murine Mammary Cells . . . . . . . . . . . . .

H. W. Lane, L. G. Wolfe, and D. Medina

The Relationship Between Manganese Intake and the Activity of Manganese Superoxide Dismutase in Tissues of Sheep . . . . . . .

D. G. Masters and D. I. Paynter

Effects of Selenium Intake on the Activity of Superoxide Dismutase and Glutathione Peroxidase and on Malondialdehyde Excretion During the Development of Rat Mammary Carcinogenesis . . . . .

M. R. L'Abbé, E. R. Chavez, P. W. F. Fischer, and K. D. Trick

Trace Elements, Free Radicals and Lipoperoxidation in Rats . . . . .

I. E. Dreosti and E. J. Partick

Contrasting Effects of Selènium and Vitamin E Deficiency on the Anti-Malarial Action of Qinghaosu in Mice . . . . . . . .

0. A. Levander, A. L. Ager, V. C. Morris, and R. May

The Effect of Selenium and Vitamin E Deficiencies on the Spin Trapping of Free Radicals in Homogenates of Rat Heart . . . .

J. R. Arthur, D. B. McPhail, and B. A. Goodman 
Trace Elements in Calcified Tissues and Matrix Biology . . . . . . .

R. B. Rucker

The Extracellular Matrix . . . . . . . . . . . . . . . .

M. E. Nimni

The Role of Trace Elements in the Development of Cartilage Matrix . 267

R. M. Leach, Jr.

Enhanced Maternal Transfer of Fluoride in the Magnesium-Deficient Rat . . . . . . . . . . . . . . . . . . . . . . . .

F. L. Cerklewski and J. W. Ridlington

Dietary Boron Affects Bone Calcification in Magnesium and Cholecalciferol Deficient Chicks . . . . . . . . . . .

C. D. Hunt and F. H. Nielsen

The Role of Copper and Cross-Linking in Elastin Accumulation . . .

D. Tinker, N. Romero, and R. Rucker

A Silicon and Aluminum Interaction in the Rat

E. M. Carlisle and M. J. Curran

MOLECULAR BIOLOGY OF TRACE ELEMENT FUNCTION AND METABOLISM

Coordinate Regulation of Zinc Metabolism and Metallothionein Gene Expression by cAMP, Interleukin-1 and Dietary Copper and Zinc .

R. J. Cousins, M. A. Dunn, T. L. Blalock, and A. S. Leinart

Metallothionein and Ceruloplasmin Genes . . . . . . . . . .

D. M. Danks and J. F. B. Mercer

Metallothionein mRNA Levels in Normal and Mottled Mouse Mutants During Development ..................

T. Stevenson, J. Camakaris, J. Mercer, and D. M. Danks

Age Dependence of Metallothionein Inducibility in Mouse Liver . . .

D. J. Thomas, S. Morris, and P. C. Huang

Cytosolic Cu-Binding Components and the Brindled Mouse Defect . . .

F. Palida, G. Waldrop, P. Lonergan, and M. Ettinger

5S Ribosomal RNA Synthesis in Zinc-Deficient Rats . . . . . .

J. K. Chesters and L. Petrie

Regulation of the Genes Involved in the Utilization of Molybdenum . 301

N. K. Amy and J. B. Miller

\section{TRACE ELEMENT INTERACTIONS 3}

Mechanisms and Nutritional Importance of Trace Element Interactions .

I. Bremner

Effects of Dietary Molybdenum and Iron on Copper Metabolism

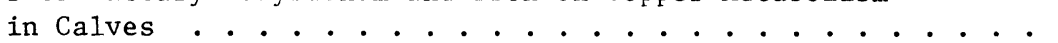

W. R. Humphries, M. J. Walker, P. C. Morrice, and I. Bremner 
Accumulation of $\mathrm{Cu}$ and Mo by the Foetus(es) and Conceptus of

Single and Twin Bearing Ewes . . . . . . . . . . . .

N. D. Grace, J. Lee, and P. L. Martinson

Influence of Breed and Dietary $\mathrm{Cu}$, Mo and $\mathrm{S}$ Levels on Biliary $\mathrm{Cu}$ Excretion in Cattle . . . . . . . . . . . . . . . . . .

S. R. Gooneratne, D. A. Christensen, J. V. Bailey, and H. W. Symonds

Interactions Between Proteins, Thiomolybdates and Copper . . . . . .

J. D. Allen and J. M. Gawthorne

Antagonistic Effects of a High Sulphur, Molybdenum and Cadmium Content of Diets on Copper Metabolism and Deficiency Symptoms in Cattle and Pigs... . . . . . . . . . . . . . . .

M. Anke, T. Masaoka, A. Hennig, and W. Arnhold

Heliotrope Alkaloids and Copper . . . . . . . . . . . . . . .

J. McC. Howel1, H. Patel, and P. Dorling

Interrelationships Between Molybdenum and Copper in Female Rats . . J.-J. Chen, M. T. Yang, and S. P. Yang

POSTERS :

\section{SELENIUM}

Effects of Transsulfuration Defects on Selenium Status . . . . . . .

M. A. Beilstein, W. A. Gahl, and P. D. Whanger

Antioxidant Supplementation for Elderly Living at a Nursing Home:

A Double-Blind Randomized One Year Clinical Trial . . . . . .

T. Westermarck, M. Tolonen, M. Halme, S. Sarna,

M. Keinonen, and U.-R. Nordberg

Evidence of Selenium Deficiency in Mice Fed a Soy-Based Diet . . . .

K. Ploetz and E. Wallace

Determination of Selenium and Multiple Stable Isotope Enrichment of Selenium in Biological Materials by Inductively

Coupled Plasma Mass Spectrometry . . . . . . . . . . . . .

W. T. Buckley, D. V. Godfrey, K. M. Koenig, and J. A. Shelford

Glutathione Peroxidase, Vitamin E and Polyunsaturated Fatty Acid Content of Tissues of Pigs with Dietetic Microangiopathy . . . .

D. Rice and S. Kennedy

Identification of Selenium Containing Proteins from Soybeans . . . .

A. C. Mason, S. K. Sathe, R. Rodibaugh, and C. M. Weaver

Influence of Dietary Methionine on Selenomethionine Metabolism in Rats

J. A. Butler and P. D. Whanger

Purification and Properties of the Human Plasma Selenoenzyme, Glutathione Peroxidase . . . . . . . . . . . . . . .

J. T. Deagen, D. J. Broderick, and P. D. Whanger

Effect of a Shipment of High-Selenium Wheat on Selenium Status of Otago (N.Z.) Residents . . . . . . . . . . . . . . . .

M. F. Robinson and C. D. Thomson 
Transfer of Selenium from Different Dietary Sources into

Plasma and Milk of Dairy Cow . . . . . . . . . . . . . .

P. Aspila and L. Syrjh1h-Qvist

Erythrocyte and Plasma Glutathione Peroxidase: Two Distinct Selenium Containing Proteins . . . . . . . . . . . . . . . .

H. Cohen, N. Avissar, K. Takahashi, and P. Allen

GSH-Px Activity in the Blood Compared with Selenium Concentration in Tissues After Supplementation of Inorganic or Organic Selenium . . . . . . . . . . . . . . . . . . . . .

E. Johansson, S.-0. Jacobsson, and U. Lindh

Selenium and Glutathione Peroxidase Status in Term Infants Fed Human Milk, Whey-Predominant, or Soy-Based Infant Formula . .

R. E. Litov, V. S. Sickles, G. M. Chan, I. R. Hargett, and A. Cordano

Influence of Cysteine on Mucosal Uptake of 75-Se-Selenite by Sheep Jejunum ... . . . . . . . . . . . . . . . .

S. Wolffram, R. WUrmli, and E. Scharrer

Distribution of Selenium and Glutathione Peroxidase in Plasma from Healthy Subjects and Patients with Rheumatoid Arthritis .

M. Borglund, A. Åkesson, and B. Akesson

Plasma Selenium and Glutathione Peroxidase in Relation to Cancer, Angina Pectoris and Short-Term Mortality in 68 Year 01d Men

B. Åkesson and B. Steen

Biological Functions of Silicon, Selenium, and Glutathione Peroxidase (GSH-Px) Explained in Terms of Semiconduction . . . . . . .

J. Parantainen, S. Sankari, and F. Atroshi

Influence of Glutathione Depletion on Hepatic Copper Uptake and Biliary Copper Excretion in the Rat .......... 361

H. Nederbragt

\section{TRACE ELEMENTS AND LIPID METABOLISM}

Effect of Zinc Deficiency on Lipid and Protein Profiles of the Rat Erythrocyte Membrane . . . . . . . . . . . . . . . .

G. L. Johanning, D. S. Miller, and B. L. O'Dell

Effects of Lead Deficiency on Lipid Metabolism . . . . . . . . .

A. M. Reichlmayr-Lais and M. Kirchgessner

An Association of Zinc with Omega-6-Fatty Acid and cAMP Synthesis in Melanoma Cells ..............

N. S. Skeef and J. R. Duncan

Effect of Non-Steroidal Anti-Inflammatory Drugs and Prostaglandin $\mathrm{E}_{2}$ on Zinc Absorption in Humans . . . . . . . . . . . . . . . .

W. S. Watson, D. A. Pitkeath1y, G. Sinclair, M. I. F. Bethel, T. D. B. Lyon, and I. Pattie

Zinc Decreases Lipid and Long Chain Fatty Acid Release from the Rat Mesenteric Vascular Bed Perfused In Vitro . . . . . . . .

S. C. Cunnane, B. A. Nassar, K. R. McAdoo, and D. F. Horrobin 
Rat Heart Performance and Lipid Metabolism is Affected by

Copper Intake . . . . . . . . . . . . . . . . . .

S. C. Cunnane, K. R. McAdoo, and M. Karmazyn

Tissue Fatty Acid Responses to Selenium and Vitamin E Deficiency and Oral C18:3,n-3 in Cattle ..............

D. Rice, S. Kennedy, and J. Blanchflower

\section{TRACE ELEMENTS AND ENDOCRINE/EXOCRINE FUNCTION}

Pancreatic Superoxide Dismutase Activity in the Copper-Depleted Rat .

A. Mylroie, A. Boseman, and J. Kyle

Controlled Exercise Effects on Chromium, Copper and Zinc in the Urine of Trained and Untrained Runners Consuming a

Constant Diet . . . . . . . . . . . . . . . . .

R. A. Anderson, M. M. Polansky, and N. A. Bryden

The Role of Zinc on the Trophic Growth Factors, Nerve Growth

Factor and Gustin . . . . . . . . . . . . . . .

R. I. Henkin, J. S. Law, and N. R. Nelson

The Effects of High and Low Chromium Yeast Supplementation on Glucose Metabolism of Noninsulin Dependent Diabetic Patients . .

C. Nan-Zheng, J. Gui-Rong, X. Xing-Yiou, Z. Mei-Fang, H. Xiao-Lin, Z. Zhong-Liang, Z. Guo-Wen, W. Jin-Fu, Y. Chang-Rong, W. Xiou-Fang, L. Xi-Zhen, and B. Zhen-Zhu

Stress Induced Changes in Indices of Zinc, Copper, and Iron Status in U.S. Navy SEAL Trainees . . . . . . . . . . . .

A. Singh, B. A. Day, J. E. DeBolt, and P. A. Deuster

Zinc-dependent Failure of Thymic Hormone in Human Pathologies . . .

N. Fabris, E. Mocchegiani, and R. Palloni

\section{TRACE ELEMENTS AND IMMUN", FUNCTION/BACTERIOLOGY}

Effect of Cobalt Deficiency on the Immune Function of Ruminants . .

A. MacPherson, G. Fisher, and J. E. Paterson

The Effect of Excess Zinc on cAMP Synthesis as a Regulatory Factor

in Tumour Cell Proliferation . . . . . . . . . . . . .

N. S. Skeef and J. R. Duncan

Zinc and the Bacteriostatic Quality of Human Milk . . . . . . .

N. F. Krebs, A. M. Novacky, R. T. Ellison III, and K. M. Hambidge

Trace Element and Macro Electrolyte Behaviour During Inflammatory

Diseases in Cattle and Sheep . . . . . . . . . . . . .

G. M. Murphy, T. D. St. George, V. Guerrini, R. G. Collins,

A. C. Broadmeadow, M. F. Uren, and D. L. Doolan

\section{TRACE ELEMENT TRANSPORT}

Genetic and Biochemical Analysis of Copper Transport in

Escherichia coli . . . . . . . . . . . . . . . .

D. Rouch, J. Camakaris, G. Adcock, and B. T. 0. Lee 
Effect of Prior Luminal Washing on Iron Absorption from Duodenum and Jejunum in Mice: Do Luminal Factors Mediate the

Absorption of Iron? . . . . . . . . . . . . . . . . . .

P. R. Flanagan, J. Haist, and L. S. Valberg

Pathobiochemical Aspects to the Mechanism of Zinc Absorption . . . .

J. D. Kruse-Jarres, E.-M. Hecht, and W. Hecht

The Effect of Saponins on Mineral Availability . . . . . . . .

S. Southon, A. J. A. Wright, I. T. Johnson, J. M. Gee, K. Price, and S. J. Fairweather-Tait

Rate of Passage of Chromium III Thru the Small Intestine . . . . .

D. Oberleas and J. C. Smith, Jr.

Cd-Binding Proteins Anchoring to Mucosal Brush Border Membrane from Rat Small Intestinal Tract . . . . . . . . . . . .

$\mathrm{N}$. Sugawara and C. Sugawara

Zinc Accumulation by Hepatocytes Isolated from Male Rats of Different Zinc Nutritional Status . . . . . . . . . . .

W. A. House, R. M. Welch, and D. Van Campen

Identification of Five Sites of Regulation of Human Zn Metabolism . .

M. E. Wastney, R. L. Aamodt, and R. I. Henkin

Saturable Zinc Uptake by Syncytiotrophoblast Microvillous Plasma Membrane Vesicles from Human Placenta . . . . . . . . .

G. Quinn, A. Flynn, and B. Lonnerda1

Nicke1 Absorption and Elimination in Human Volunteers ........

F. W. Sunderman, Jr., S. M. Hopfer, T. Swift, L. Ziebka, A. H. Marcus, B. M. Most, and J. Creason

Influence of Feed Components in Semisynthetic Diets on Cadmium Retention in Chicks . . . . . . . . . . . . . . . . . .

W. A. Rambeck, R. Hettich, D. Berg, and W. E. Kollmer

The Effect of Dietary Fiber and Different Concentrations of Zinc on the Intestinal Absorption of Cadmium in Rats . . . . . . .

A. Moberg, G. Hallmans, R. Sjöström, and K. Wing

Transferrin Receptors and Iron Uptake of Rat Mammary Gland Membranes During Lactation . . . . . . . . . . . . . . .

M. Sigman and B. Lönnerdal

\section{TRACE ELEMENT DEFICIENCIES AND THEIR ASSESSMENT}

Prediction of Disorder in Cu-Deficient Lambs from Different Genotypes . . . . . . . . . . . . . . . . . . . .

N. F. Suttle, D. G. Jones, J. A. Woolliams, and C. Woolliams

Metal Analysis of Human Liver as an Aid to Diagnosis . . . . . . .

D. McMaster, M. E. Callender, and A. H. G. Love

The Use of Multivariate Analysis to Identify Limiting Trace

Elements in Sheep ..................

D. B. Purser, D. G. Masters, P. L. Payne, and R. Maller 
Concentration and Distribution of Zinc, Copper and Iron in

"Zinc Deficient" Human Milk . . . . . . . . . . . .

S. A. Atkinson and B. Lönnerdal

Effects of Heat Treatment of Defatted Soy Flour Fed to Young

Japanese Quail . . . . . . . . . . . . . . . .

S.-H. Tao, M. R. S. Fox, B. E. Fry, Jr., and W. H. Stroup

Comparison of Indices of Copper Status in Men and Women Fed

Diets Marginal in Copper . . . . . . . . . . . . . .

D. B. Milne, L. M. Klevay, and J. R. Hunt

Beer Increases the Longevity of Rats Fed a Diet Deficient

in Copper .....................

L. M. Klevay

The Influence of Zinc Deficiency on the Storage of Zinc in Bone . .

D. Berg and W. E. Kollmer

Evaluation of Some Factors That May Affect Plasma or Serum

Zinc Concentrations . . . . . . . . . . . . . . .

J. L. English, K. M. Hambidge, and M. Jacobs Goodall

Ceruloplasmin and Glutathione Peroxidase as Copper and Selenium Indicators in Mink . . . . . . . . . . . . . . .

J. T. Tydpponen

Copper and Iron Status of Calves in Relation to Plasma Protein Polymorphism ....................

I. Wegger

Further Data on the Biological Essentiality of Nickel . . . . . .

M. Anke, B. Groppe1, U. Krause, and M. Langer

Altered Glucuronyl Transferase Activity in Magnesium Depleted Rats . .

R. C. Brown and W. R. Bidlack

The Prediction of Impaired Growth Due to $\mathrm{Cu}$, Co and Se Deficiencies in Lambs on Improved Hill Pastures in Scotland .

N. Suttle, C. Wright, A. MacPherson, R. Harkess, G. Halliday, K. Miller, P. Phillips, C. Evans, and D. Rice

Zn Deficiency in the Rat: Relationship between Growth and Metal Content and Distribution . . . . . . . . . . . . .

D. H. Petering and B. Fowler

Activation of Rat Erythrocyte Superoxide Dismutase by Copper . . .

R. A. Disilvestro

\section{TRACE ELEMENTS AND CLINICAL NUTRITION}

Kinetics of Chromium in Patients on Continuous Ambulatory Peritoneal Dialysis . . . . . . . . . . . . . . . .

B. Wallaeys, R. Cornelis, N. Lameire, and M. Van Landschoot

The Influence of Body Mass Index and Hypoglycaemic Drugs on the Circulating and Excreted Levels of Chromium Following an Oral Glucose Challenge, in Subjects With and Without Diabetes Mellitus. . . . . . . . . . . . . . . .

K. E. Earle, A. G. Archer, J. E. Baillie, and A. N. Howard 
Serum Aluminum Levels in Dialysis Patients . . . . . . . . . .

Y. Schmitt and J. D. Kruse-Jarres

Dietary Intakes and Serum Levels of Selected Trace Elements in Institutionalized Elderly . . . . . . . . . . . . . . .

M. Allegrini, E. Lanzola, A. Tagliabue, G. Turconi, and $\mathrm{C}$. Tinelli

Mineral Status of Adults Given a Fiber Supplement . . . . . . . .

S. J. Fairweather-Tait, Z. Piper, and S. Southon

Daily Variations in Plasma Zinc in Normal Adult Women . . . . . .

M. Jacobs Goodal1, K. M. Hambidge, C. Stall, J. Pritts, and D. E. Nelson

Urinary Excretion (24 Hours) of Zinc and Copper in Normal Vegetarian and Non-Vegetarian Female Subjects During the Different

Seasons: A Preliminary Studies .............

V. Iyengar

Hepatic Trace Elements in Kwashiorkor . . . . . . . . . . .

J. Miles, M. Golden, D. Ramdath, and B. Golden

\section{TRACE ELEMENT BIOAVAILABILITY}

Improved Zinc Bioavailability from Colloidal Calcium Phosphate-Free Cow's Milk . . . . . . . . . . . . . . .

J. Kiely, A. Flynn, H. Singh, and P. F. Fox

Effects of Soybean Trypsin Inhibitor on Tissue Zinc in Weanling

Male Long-Evans Rats . . . . . . . . . . . . . 501

J. I. Rader, S.-H. Tao, and M. R. S. Fox

Calcium and Zinc Absorption from Human Milk, Soy Formula and Dephytinized Soy Formula . . . . . . . . . . . . . .

C. Kunz and B. Lobnnerdal

Distribution of Zinc in Human Milk and Cow's Milk after

In Vitro Proteolysis

B. Lbnnerdal and C. Glazier

The Availability of Zinc, Cadmium and Iron from Different Grains Measured as Isotope Absorption and Mineral Accumulation in Rats . . . . . . . . . . . . . . . . .

P. Tidehag, A. Moberg, B. Sunze1, G. Ha11mans, R. Sjbström, and $\mathrm{K}$. Wing

Bioavailability of Iron Fortification Compounds Assessed by a Rat Model

E. R. Morris, J. T. Tanner, and C. Adams

Manganese Absorption from Human Milk, Cow's Milk and Infant Formulas .

L. Davidsson, A. Cederblad, B. LÖnnerdal, and B. Sandström

Influence of Calcium and Phosphorus on the Absorption of Manganese as Determined by Plasma Uptake Tests . . . . . . . . . . .

J. Freeland-Graves and P.-H. Lin

Tissue Uptake of Manganese as a Measure of Its Bioavailability for Chicks .. . . . . . . . . . . . . . . . . 515

C. B. Ammerman, J. R. Black, P. R. Henry, and R. D. Miles 
An Epidemiological Study of a Defined Area of N. Ireland: Whole Blood Glutathione Peroxidase (EC 1.11.1.9) . . . . . .

D. McMaster, A. E. Evans, E. McCrum, M. McF. Kerr, C. C. Patterson, and A. H. G. Love

Hair Chromium as an Index of Chromium Status of Tannery Workers . . 519

J. Randa11 and R. Gibson

Familial Trends in Heavy Trace Metal Body Burdens in a Small Rural Community ....................

D. J. Eatough, N. F. Mangelson, M. W. Hill, K. K. Nielsen, L. D. Hansen, and M. A. Skolnick

Cadmium, Zinc and Calcium in Human Kidneys . . . . . . . . . . .

R. Scott, E. Aughey, and A. McLelland

Ante Mortem v. Post Mortem Changes in Chronic Cadmium Poisoning . .

R. Scott and E. Aughey

Accurate Assessment of the Intake of Dietary Components by Human Subjects . . . . . . . . . . . . . . .

V. Iyengar

Reference Values for Trace Element Concentrations in Whole Blood, Serum, Hair, Liver, Milk, and Urine Specimens from Human Subjects ..............

V. Iyengar

Trace Elements in Human Milk: An Australian Study . . . . . . .

F. J. Cumming and J. J. Fardy

\section{TRACE ELEMENT INTERACTIONS}

Copper and Molybdenum Levels in Tissues of Hypercuprotic Sheep During and After Being Fed Different Levels of Molybdenum . . 541

J. B. J. van Ryssen and P. R. Barrowman

Increased Sulfide Concentration in the Rumen Fluid of Sheep Does Not Decrease the Solubility of Copper ...........

H. Nederbragt, H. Kersten, M. Klomberg, and A. J. Lagerwerf

Effect of High Dietary Iron and Ascorbic Acid on Copper and Iron Utilization During Copper Deficiency . . . . . . . . .

M. A. Johnson and C. L. Murphy

Interaction of Gold and Selenium after Injection to Mice . . . . . . 547

J. Aaseth, J. Alexander, and E. Steinnes

Effects of Arsenic on the Intestinal Absorption of ${ }^{75} \mathrm{Se}$ Compounds in Chicks

H. Mykkahnen

Chromium and Vanadate Supplementation of Obese and Lean Mice . . . . 553

B. J. Stoecker and Y. C. Li

The Effect of Parenteral Iron Administration upon Manganese Metabolism ...................

N. Gruden 
The Effect of Age and Sex upon Iron-Manganese Interaction in

Different Segments of the Rat's Intestine . . . . . . . .

N. Gruden

Minera1-Zinc and Protein-Zinc Interactions in Man . . . . . . .

H. Spencer, S. J. Sontag, and D. Osis

Mineral Balance Study of Rats Fed Maillard Reaction Products . . . .

J. M. O'Brien, P. A. Morrissey, and A. Flynn

Binding of Zinc to Colloidal Calcium Phosphate . . . . . . . .

H. Singh, A. F1ynn, and P. F. Fox

Iron-Zinc Interactions in Relation to Infant Weaning Foods . . . . .

S. J. Fairweather-Tait and S. Southon

Iron Status of Very Low Birthweight Pre-Term Infants Receiving

a Zinc Supplement . . . . . . . . . . . . . . . . .

J. Frie1, M. Cox, A. Corne1, D. Matthew, and W. Andrews

Production of $\mathrm{Mg}$ Deficiency Anemia by $\mathrm{Zn}$ and Phytate in

Young Japanese Quail ..................

M. R. S. Fox, S.-H. Tao, B. E. Fry, Jr., and Y. H. Lee

Hepatic and Splenic Content of Iron, Copper, Zinc, and

Manganese in Anemic Mink . . . . . . . . . . . . . . .

J. T. Tyßpponnen and P. O. Lindberg

Copper Status and Cadmium Administration: Effects on Zinc Distribution, Metallothionein, and Superoxide Dismutase Activity in Liver . . . . . . . . . . . . . . . . . 579

K. Chung, D. Tinker, N. Romero, K. Amemiya, C. Keen, and R. Rucker

Boron and Methionine Status of the Rat Affects the Plasma and Bone Mineral Response to High Dietary Aluminum . . . . . . 581

T. R. Shuler and F. H. Nielsen

Effect of Molybdenum on Hepatic Enzymes and Minerals of Female Rats . . . . . . . . . . . . . . . . . . .

M. T. Yang and S. P. Yang

An Interaction Between Dietary Vanadium and Riboflavin in Chicks... 585 C. H. Hill

Demonstration of Ruminal Synthesis of Thiomolybdates and Their Subsequent Absorption in Sheep . . . . . . . . . . . . .

J. Price, A. M. Will, G. Paschaleris, and J. K. Chesters

High Resolution Gamma-Ray Spectroscopy as an in vivo Tool

for Following the Zinc-Selenium Interaction . . . . . . . .

K. R. Zinn and J. S. Morris

Effect of Fe Supplementation on Zn Status and the Outcome of Pregnancy . . . . . . . . . . . . . . . . . . . .

J. M. McKenzie-Parne11, P. D. Wilson, and G. F. S. Spears

Human Metabolic Study of Milk Simultaneously Fortified with Zinc, Iron and Copper .. . . . . . . . . . . . . . .

B. Momcilovic, M. J. Jackson, J. M. Round, and T. B. Weir 
Age-Related Changes in Zinc and Copper Concentrations of Serum, Kidney, Liver, and Five Parts of the Brain of the Adult Rat . .

R. Palm, G. Wahlstrom, and G. Hallmans

Zinc Uptake by Brush Border Membrane Vesicles (BBMV) from

Pre-Weanling Rat Small Intestine . . . . . . . . . . .

M. L. Kennedy and B. Lönnerdal

Maternal Glucose Homeostasis in Rats Given Marginal Zn Diets . . . .

S. Southon, C. M. Williams, and S. J. Fairweather-Tait

Pregnancy Complications, Labor Abnormalities and Zinc Status . . . .

N. Lazebnik, B. R. Kuhnert, P. M. Kuhnert, and K. Thompson

Is Spina Bifida in Man Linked to a Genetic Defect of Cellular Zinc Uptake in Children? . . . . . . . . . . . .

A. Favier, B. Dardelet, M.-J. Richard, and J. Arnaud

Effects of Varying Dietary Zinc in Mice During Recovery from Undernutrition . . . . . . . . . . . . . . . . . .

P. N. Morgan, C. L. Keen, G. H. Cardinet III and B. Lobnnerda1

Altered Mineral Metabolism as a Mechanism Underlying the Expression of Fetal Alcohol Syndrome in Rats . . . . . . . .

S. Zidenberg-Cherr, J. Rosenbaum, and C. L. Keen

Action of High Dietary Copper in Promoting Growth of Pigs . . . . .

G. C. Shurson, P. K. Ku, G. L. Waxler, M. T. Yokoyama, and E. R. Miller

The Accumulation of Copper, Zinc, Manganese and Iron in the Foetus of Deer . . . . . . . . . . . . . . . . .

R. Hill, M. Leighton, V. Heys, and D. M. Jones

Effects of Molybdenum on Reproduction and Molybdenum/Copper Enzyme Activity in the Female Rat . . . . . . . . . . .

T. V. Fungwe, F. Buddingh, M. T. Yang, and S. P. Yang

Defective Hepatic Copper Storage in the Brindled Mouse . . . . . .

A. Garnica, M. Perry, J. Bates, and 0. Rennert

Zinc, Copper and Iron Metabolism by Turkey Embryo Hepatocytes . . . .

M. P. Richards and N. C. Steele

Perinatal Development of Superoxide Dismutase in Rat Liver and Kidney . . . . . . . . . . . . . . . . .

T. Glinther and J. Vormann

The Amenity and Annoyance: The Circadian Rhythm, the Function of Limbic System and the Metal Metabolism in Mice . . . . . .

$\mathrm{K}$. Hoshishima

Marginal Zn Deficiency Affects Pup Brain Microtubule Assembly in Rats . . . . . . . . . . . . . . . .

P. I. Oteiza, C. L. Keen, B. Lonnerdal, and L. S. Hurley

Effects of Maternal Dietary Zinc on the Expression of Diabetes-Induced Teratogenicity in the Rat ..........

J. Y. Uriu-Hare, J. S. Stern, and C. L. Keen 
The Effect of Monensin Sodium on Trace Element Status of

Cattle at Pasture . . . . . . . . . . . . . . . . .

N. D. Costa

The Effects of Differing Compositions of Soluble Phosphate Glass Boluses on the Copper, Cobalt and Selenium Status of Swaledale Ewes . . . . . . . . . . . . . . . .

P. M. Driver, C. Eames, and S. B. Telfer

The Effects of Soluble Glass Boluses upon the Copper and Selenium Status of Grazing Cattle . . . . . . . . . . . . .

P. M. Driver, C. Eames, and S. B. Telfer

The Effect of Different Compositions of Soluble Phosphate Glass Boluses on the Copper and Vitamin B12 Status of Growing Lambs . . . . . . . . . . . . . . . . . . . .

P. M. Driver, C. Eames, and S. B. Telfer

A Preliminary Assessment of Controlled Release Devices for Supplementing Grazing Sheep with Trace Elements . . . . . . . .

D. W. Peter and K. J. Ellis

Efficacy of Selenium Pellets in Beef Cows . . . . . . . . . . . . 647

W. H. Johnson, B. B. Norman, J. R. Dunbar, and M. N. Oliver

The Development of a Long Acting Injectable Preparation for the Treatment and Prevention of Selenium Deficiency in Cattle . . .

I. M. McPhee and G. D. Cawley

Effect of Oral Copper Needles and Parenteral Copper on Hypocupraemia, Body Weight Gain and Fertility in Cattle . . . . .

B. E. Ruksan, M. Correa Luna, and F. Lagos

Oxidized Copper Wire Particles as an Oral Copper Supplement for Cattle... . . . . . . . . . . . . . . . . .

J. R. Dunbar, J. G. Morris, B. B. Norman, A. J. Jenkins, C. B. Wilson, N. L. Martin, and J. M. Connor

Investigations on Vanadium Deficiency in Ruminants . . . . . . . . . .

M. Anke, B. Groppel, T. Kosla, and K. Gruhn

Possibilities of Diagnosing Iodine Deficiency in Ruminants . . . . .

B. Groppe1, M. Anke, and A. Hennig

Normal Manganese, Zinc, Copper, Iron, Iodine, Molybdenum, Nickel, Arsenic, Lithium and Cadmium Supply Dependent on the Geological Origin of the Site and Its Effects on the Status of These Elements in Wild and Domestic Ruminants . . . . . . . . . . . . . . . . . . . .

M. Anke, B. Groppe1, U. Krause, L. Angelow, W. Arnhold, T. Masaoka, S. Barhoum, and G. Zervas

Pathology of Experimental Nutritiona1 Degenerative Myopathy in Ruminant Cattle . . . . . . . . . . . . . . . . .

S. Kennedy and D. Rice

Treatment of Dairy Sheep with Soluble Glass Boluses . . . . . . . .

G. Zervas 
Hormonal Modulation of Rat Hepatic Zinc Metallothionein Leve1s . . .

S. H. Garrett, K. Arizono, and F. 0. Brady

Effects of Zn-Deficiency and Valproate on Isometallothioneins

in Fetal Rat Liver . . . . . . . . . . . . . . .

J. Vormann and T. Gunther

Uninduced $\mathrm{Cu}$-Metallothionein and Other $\mathrm{Cu}$-Binding Proteins in Mammals and Fish ..................

D. H. Petering, S. Krezoski, T. Hartmann, P. Chen, P. Onana, and C. F. Shaw III

Instability at Low $\mathrm{pH}$ of Copper-Thionein-Proteins from Livers of Bedlington Terriers with Copper-Toxicosis . . . . . . . .

H. Nederbragt, A. J. Lagerwerf, and T. S. G. A. M. van den Ingh

Zinc, Copper and Metallothionein mRNA in Sheep Liver During Development . . . . . . . . . . . . . . .

J. F. B. Mercer, J. Smith, A. Grimes, J. McC. Howe11, P. Gi11, and D. M. Danks

Metallothionein Concentrations in the Blood and Urine of Streptozotocin Treated Rats ..............

I. Bremner, J. N. Morrison, and A. M. Wood

Effects of Metallothionein Binding Capacity for Various Metals on Heme Oxygenase Activity . . . . . . . . . . . . . .

$\mathrm{K}$. Arizono, E. Okanari, K. Ueno, and T. Ariyoshi

\section{HOMEOSTASIS OF TRACE ELEMENTS}

The Effect of Dietary $\mathrm{Zn}$ Before and After 65-Zn Administration on Absorption and Turnover of $65-\mathrm{Zn}$. ............

J. R. Hunt, P. E. Johnson, and P. B. Swan

Effect of Long-Term Trace Element Supplementafion on B1pod Trace Element Levels and Absorption of ${ }^{5} \mathrm{Se},{ }^{54} \mathrm{Mn}$ and

B. Sandstrym, L. Davidsson, R. Eriksson, and M. Alpsten

Retention of Lead in Growing and Adult Rats Dependent on Varying Lead Supply .....................

M. Kirchgessner, A. M. Reich1mayr-Lais, and N. K. St8̈ck1

Zinc Losses During Prolonged Cold Water Immersion . . . . . . .

P. A. Deuster, D. J. Smith, A. Singh, L. L. Bernier,

U. H. Trostmann, B. L. Smoak, and T. J. Doubt

Metabolic Adaptation of Gilts on Trace-Minerals in Response to Pregnancy and Low Dietary Zinc .............

E. R. Chavez and J. Kalinowski

\section{TRACE ELEMENT TOXICITY AND ITS PATHOLOGY}

An Episode of Zinc Toxicosis in Milk-Fed Holstein Bull Calves:

Pathologic and Toxicologic Considerations . . . . . . . .

T. W. Graham, C. L. Keen, C. A. Holmberg, M. C. Thurmond, and M. S. Clegg 
Copper Tolerance in Rats - A Histochemical and

Immunocy tochemical Study . . . . . . . . . . . . . . .

M. Elmes, S. Haywood, J. P. Clarkson, I. C. Fuentealba, and B. Jasani

Toxicosis of Developing Pigs Fed Selenium from Various

Sources: Clinical Pathology . . . . . . . . . . . 701

D. Baker, L. James, K. Panter, H. Mayland, and J. Pfister

Aluminum Induced Alteration in Hepatic Glucurony 1

Transferase Activity . . . . . . . . . . . . . . 703

M. S. Meskin, R. C. Brown, and W. R. Bidlack

Decrease of Serum Triglyceride and Essential Metal Changes

in Normal Rats Fed with 2000 ppm Aluminum Diets . . . . . . 705

C. Sugawara and N. Sugawara

Tissue Concentrations of Molybdenum After Chronic Dosage

in Rats do not Follow Size of Dose . . . . . . . . . . . . 709

P. W. Winston and L. J. Kosarek

Metallothionein and Copper in Human Liver -

A Histopathological Study ................. 711

M. E. Elmes, J. P. Clarkson, B. Jasani, and N. J. Mahy

\section{ANALYTICAL TECHNIQUES}

The Elemental Content of Some Trace Element Medicaments by Proton-Induced X-Ray and Gamma-Ray Emission Analyses . . . . 713

P. Nikkinen, M. Hyvbnen-Dabek, and T. Westermarck

The Application of a Synchrotron Radiation Microprobe to Trace Element Analysis . . . . . . . . . . . . . 715

B. M. Gordon, A. L. Hanson, K. W. Jones, W. M. Kwiatek, G. J. Long, J. G. Pounds, G. Schidlovsky, P. Spanne, M. L. Rivers, and S. R. Sutton

Automated Determination of Blood Glutathione Peroxidase and the Effect of Storage, Cyanide and Drabkin's Reagent . . . . .

W. J. Blanchflower, D. A. Rice, and W. B. Davidson

Chemical Speciation of Metal Ions in the Ruminal and Abomasal Fluid of Sheep

$\mathrm{J}$. Lee 